\title{
Diagnostic Excellence in the ICU: Thinking Critically and Masterfully
}

Editors

PAUL A. BERGL RAHUL S. NANCHAL

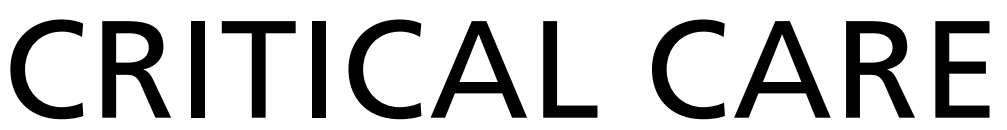
CLINICS

www.criticalcare.theclinics.com

Consulting Editor GREGORY S. MARTIN

January 2022 • Volume 38 - Number 1 